\title{
Multiplex PCR assay for detection of four major bacterial pathogens causing rainbow trout disease
}

\author{
Ilhan Altinok* \\ Karadeniz Technical University, Faculty of Marine Sciences, 61530 Surmene, Trabzon, Turkey
}

\begin{abstract}
A multiplex PCR (mPCR) method was designed for the simultaneous detection of 4 major fish pathogens, Flavobacterium psychrophilum, Lactococcus garvieae, Pseudomonas aeruginosa, and $P$. putida. Each of the 4 pairs of oligonucleotide primers exclusively amplified the 16S rDNA gene of their targeted microorganism. The average detection limits for each organism amplified by mPCR were 2 colony-forming units (CFU) of $F$. psychrophilum, 3 CFU of L. garvieae, 3 CFU of $P$. aeruginosa, and $5 \mathrm{CFU}$ of $P$. putida in mixed cultures. Multiplex PCR did not produce any nonspecific amplification products when tested against 28 related species of bacteria. High amounts of DNA from 1 bacterial species had a significant effect on the amplification sensitivity of the other bacterial species when these were present in lower concentrations in the multiplex reaction. The mPCR assay proved useful for the detection of the bacteria in naturally infected fish. The assay is a sensitive, specific, and reproducible diagnostic tool for the simultaneous detection of 4 pathogenic bacteria that cause disease in fish and offers a potentially useful alternative to the conventional culture-based method.
\end{abstract}

KEY WORDS: Target and non-target DNA interactions $\cdot$ Bacterial coldwater disease - Streptococcosis $\cdot$ Pseudomonas spp. infection $\cdot$ Multiplex PCR $\cdot$ Sensitivity test $\cdot$ Specificity test

\section{INTRODUCTION}

Major fish diseases of rainbow trout Oncorhynchus mykiss include bacterial coldwater diseases, streptococcosis, Pseudomonas infection, and P. putida infection caused by Flavobacterium psychrophilum, Lactococcus garvieae, $P$. aeruginosa, and $P$. putida, respectively. These diseases are common worldwide and result in considerable economic losses in the fish farming industry (Plumb 1999, Woo \& Bruno 1999, Altinok et al. 2006, Hossain et al. 2006, Austin \& Austin 2007). Disease caused by L. garvieae, P. aeruginosa, and $P$. putida in particular are very important because these pathogens can infect animals other than fish, including humans (Spanoghe 1984, Elliott et al. 1991, Hudson et al. 1993, Bouallegue et al. 2004, Evans et al. 2006). F. psychrophilum infects only fish.

Traditionally the diagnosis of a disease is obtained by culturing bacteria on agar plates followed by phe- notypic and serological characterization of the pathogen, or by histological examination (Bernardet et al. 1990, Pazos et al. 1996). Biochemical tests, DNA homology, and protease variability techniques have also been used (Pyle \& Shotts 1980, Bertolini \& Rohovec 1992, Chen et al. 1995), but these techniques have some disadvantages, such as the need for initial isolation of the pathogen and insufficient sensitivity to detect low levels of pathogen.

Molecular techniques such as polymerase chain reaction (PCR) can be used to solve the above issues and increase sensitivity and specificity of pathogen detection. Singleplex PCR assays have been developed for detection and identification of fish pathogens. However, a large number of individual PCR reactions would be necessary if single primer sets were used to screen a large number of clinical samples, resulting in a relatively costly and time-consuming process. The simultaneous detection of several pathogens with a 
Table 1. Cultures of Flavobacterium psychrophilum, Lactococcus garvieae, Pseudomonas aeruginosa, and P. putida strains used in this study, and additional taxonomically and/or ecologically related bacterial species used in cross-reactivity testing of the multiplex PCR assay. ATCC: American Type Culture Collection, Rockville, MD; CECT: Coleccion Espanola de Cultivos Tipo, Universidad de Valencia, Spain; AL, AU, CA, GA, and SC strains provided by K. Hayden, Auburn University, Department of Fisheries and Allied Aquaculture, Auburn, AL; DSMZ, G27P3, M300GFFa1, PP60-1, 137/4/98, and DSMZ 20576 strains provided by A. Manfrin, Istituto Zooprofilattico Sperimentale delle Venezie, Adria, Italy; FPF strains provided by T. Wiklund, Laboratory of Aquatic Pathobiology, Abo Akademi University, Finland. The remaining strains were isolated in the Faculty of Marine Sciences, Trabzon, Turkey

\begin{tabular}{|c|c|}
\hline Species & Strain(s) \\
\hline Flavobacterium psychrophilum & ATCC 49418, FPF \\
\hline Lactococcus garvieae & $\begin{array}{l}\text { ATCC 49156, G27P3, } \\
\text { M300GFFa1, PP60-1 }\end{array}$ \\
\hline Pseudomonas aeruginosa & ATCC 27853 \\
\hline P. putida & NCIB 8251, TSUR0501 \\
\hline Aeromonas hydrophila & $\begin{array}{l}\text { ATCC } 43874, \text { AU9833, } \\
\text { AU9738, AU0606 }\end{array}$ \\
\hline A. salmonicida salmonicida & $\begin{array}{l}\text { ATCC 49385, GA97030, } \\
\text { TN9716, RY0701 }\end{array}$ \\
\hline A. sobria & AL94232, AL9425 \\
\hline A. veroni & AL0548 \\
\hline Bacillus cereus & ATCC 11778 \\
\hline Edwarsiella tarda & AU0338, A19938 \\
\hline E. ictaluri & $\begin{array}{l}\text { ATCC 33202, AL9549, } \\
\text { AU9828, AU9738 }\end{array}$ \\
\hline Enterobacter faecalis & ATCC 2942 \\
\hline Escherichia coli & NCTC 12900 \\
\hline F. columnare & $\begin{array}{l}\text { NCIMB 2248, CA0402, } \\
\text { SC0406, AL0435 }\end{array}$ \\
\hline F. branchiophilum & ATCC 35035 \\
\hline Hafnia alvei & TSUR0702 \\
\hline Listeria monocytogenes & ATCC 7644 \\
\hline Plesiomonas shigelloides & AL9354, AL98051 \\
\hline Pseudomonas anguilliseptica & $137 / 4 / 98$ \\
\hline P. dilafialdi & RB0704 \\
\hline P. flourescens & $\begin{array}{l}\text { AU9233, AU9738, } \\
\text { AU9833 }\end{array}$ \\
\hline P. luteola & TSUC0704 \\
\hline Renibacterium salmoninarum & TS0601 \\
\hline Salmonella enterica & ATCC 14028 \\
\hline Streptococcus aureus & ATCC 25923 \\
\hline S. iniae & DSMZ 20576 \\
\hline Vibrio fluvialis & CECT 4217 \\
\hline$V$. alginolyticus & CECT 52 \\
\hline V. parahaemolyticus & CECT 511 \\
\hline$V$. mimicus & CECT 4218 \\
\hline Yersinia ruckeri & $\begin{array}{l}\text { ATCC 29473, GA97016, } \\
\text { ESU0701, EL0701 }\end{array}$ \\
\hline$Y$. pestis & TA0707 \\
\hline
\end{tabular}

multiplex PCR (mPCR) approach would be relatively rapid and cost effective. Although $\mathrm{MPCR}$ has been widely applied to the detection of multiple viruses and bacteria in clinical specimens, it is not a common tool for the detection of fish pathogens (Brasher et al. 1998, Osorio et al. 2000, del Cerro et al. 2002, Mata et al. 2004, Altinok et al. 2008). In this investigation, an mPCR assay was developed for the simultaneous detection of Flavobacterium psychrophilum, Lactococcus garvieae, Pseudomonas aeruginosa, and P. putida from pure cultures, spiked samples, and diseased/ naturally infected fish.

\section{MATERIALS AND METHODS}

Sources of fish. Rainbow trout Oncorhynchus mykiss from 32 farms in northeast Turkey were surveyed for Flavobacterium psychrophilum, Lactococcus garvieae, Pseudomonas aeruginosa, and P. putida between 2006 and 2009. Fish were sampled and examined in each season from all farms. The samples were usually comprised of 6 fish farm ${ }^{-1}$ season ${ }^{-1}$ (Dalsgaard \& Madsen 2000, Altinok et al. 2008). Diseased fish were preferentially sampled if present; otherwise, asymptomatic fish were sampled.

Bacterial strains and culture conditions. The $\mathrm{MPCR}$ assay was evaluated using the following strains: Flavobacterium psychrophilum (ATCC 49418, FPF), Lactococcus garvieae (ATCC 49156, G27P3, M300GFFa1, PP60-1, TS0901), Pseudomonas aeruginosa (ATCC 27853), and P. putida (NCIB 8251, TSUR0501, TM0905). Strains of other species taxonomically and/or ecologically related were tested as negative controls (Table 1).

Lactococcus garvieae, Pseudomonas aeruginosa, and $P$. putida strains were grown in tryptic soy broth (TSB) and were incubated at $25^{\circ} \mathrm{C}$ for $2 \mathrm{~d}$. Flavobacterium psychrophilum was grown in modified Anacker and Ordal broth (MAOB) and incubated at $18^{\circ} \mathrm{C}$ for $4 \mathrm{~d}$. All of the cultures were incubated with shaking at $250 \mathrm{rpm}$ in an orbital incubator.

Bacterial examination of rainbow trout. A total of 780 fish ranging between 4 and $300 \mathrm{~g}$ were transported to the laboratory on ice and dissected for subsequent bacteriological examination. All sampled fish were examined externally and internally. Samples from external lesions, if present, were streaked on modified Anacker and Ordal (MAO) agar (Toranzo \& Barja 1993) and tryptic soy agar (TSA). The body surface of the fish was then swabbed using $70 \%$ ethyl alcohol to prevent contamination of samples taken from internal organs by normal external bacterial flora. Liver, trunk kidney, and spleen were aseptically streaked on TSA and MAO agar and incubated at $25^{\circ} \mathrm{C}$ for $2 \mathrm{~d}$ or at $18^{\circ} \mathrm{C}$ for $4 \mathrm{~d}$, respectively. Bacteria isolated from fish were 
subcultured on the same medium to check purity of the isolate. Pure cultured colonies were biochemically characterized with API Strips (Biomerieux) and the following biochemical tests: Gram staining, cytochrome oxidase, oxidation/fermentation, catalase, hemolysis on sheep blood agar, hippurate hydrolysis, pyrronidonyl arylamidase, leucine aminopeptidase, $\beta$-galactosidase, $\beta$-glucosidase, $\beta$-glucuronidase, $\beta$-mannosidase, alkaline phosphatase, N-acetyl- $\beta$-glucosaminidase, alanine-phenylanaline-proline arylamidase, arginine dihydrolase, lysine decarboxylase, ornithine decarboxylase, citrate utilization, $\mathrm{H}_{2} \mathrm{~S}$ production, urease, tryptophane deaminase, indole production, Voges-Proskauer, and gelatinase, fermentation of glucose, mannitol, inositol, sorbitol, rhamnose, saccharose, amygdalin, melibiose, lactose, methyl red, and arabinose tests. Isolates were identified by standard bacterial taxonomy procedures (Cowan 1974, Frerichs 1984, Krieg \& Holt 1984, Lennette et al. 1985, Holt et al. 1994, Austin \& Austin 2007). All isolates were stored in a broth culture supplemented with 15 to $20 \%$ glycerol at $-70^{\circ} \mathrm{C}$.

DNA extraction from fish tissue. For DNA extraction, from the same fish, a total weight of $0.5 \mathrm{~g}$ of a liver, spleen, and trunk kidney mixture was mixed with an equal volume of lysis buffer $(200 \mathrm{mM} \mathrm{NaCl}$, $10 \mathrm{mM}$ Tris- $\mathrm{HCl}$ at $\mathrm{pH} 8.0,1 \%$ sodium dodecyl sulfate, and $50 \mathrm{mM}$ EDTA) and $5 \mu \mathrm{l}$ of Proteinase $\mathrm{K}$ solution $\left(20 \mathrm{mg} \mathrm{ml}^{-1}\right)$ in TE buffer $(10 \mathrm{mM}$ Tris- $\mathrm{HCl}$ and $0.1 \mathrm{mM}$ EDTA at pH 8.0). If external lesions were present, $0.5 \mathrm{~g}$ of gill, skin, and fin tissue were also taken for DNA extraction. The lysis buffer and TE buffer were prepared with DNase- and RNase-free ultra pure autoclaved water. Samples were incubated at $60^{\circ} \mathrm{C}$ for $16 \mathrm{~h}$. After extraction of the DNA with a mixture of phenolchloroform-isoamyl alcohol (50:48:2; Altinok et al. 2001), the DNA was precipitated at $-20^{\circ} \mathrm{C}$ for $2 \mathrm{~h}$ by adding $0.6 \mathrm{ml}$ of ice-cold $100 \%$ ethanol, then centrifuged at $21000 \times g$ for $20 \mathrm{~min}$ at $4^{\circ} \mathrm{C}$ and the ethanol was decanted. The DNA was centrifuged following addition of $70 \%$ ethanol at $21000 \times g$ for $20 \mathrm{~min}$ at $4^{\circ} \mathrm{C}$ and dried overnight. DNA was suspended in $100 \mu \mathrm{TE}$ buffer, quantified spectrophotometrically, diluted to $100 \mathrm{ng} \mathrm{ll}^{-1}$, and stored at $4^{\circ} \mathrm{C}$ until the PCR (Altinok et al. 2008).

DNA extraction from bacterial cultures. Bacterial cultures were centrifuged at $9000 \times g$ for $5 \mathrm{~min}$. Supernatant was discarded and the pellet was dissolved in $765 \mu \mathrm{l}$ TE buffer, $50 \mu \mathrm{l}$ of $10 \%$ SDS, and $5 \mu$ l Proteinase $\mathrm{K}(60 \mu \mathrm{g})$. After $1 \mathrm{~h}$ of incubation at $37^{\circ} \mathrm{C}, 100 \mu \mathrm{l}$ of $5 \mathrm{M} \mathrm{NaCl}$ were added and mixed thoroughly. Then $80 \mu \mathrm{l}$ cetyltrimethylammonium bromide were mixed with the sample, which was incubated at $65^{\circ} \mathrm{C}$ for $10 \mathrm{~min}$ (Altinok et al. 2001). The DNA was then purified as described above for tissue samples, resuspended in $100 \mu \mathrm{l}$ TE buffer, quantified spectrophotometrically, and stored at $4^{\circ} \mathrm{C}$ until required.

PCR conditions. A number of primer pairs were designed from the 16S rDNA of each target pathogen using Jellyfish software (Field Scientific). The primer sequences were used to search public databases using BLAST (http://blast.ncbi.nlm.nih.gov) for homologous matches. None were found. Primer pairs were tested (data not shown) against single pure bacterial cultures of all bacterial species listed in Table 1. For each bacterium, 1 primer set was selected that did not crossreact with other bacterial DNA and did not form primer dimers. Primers for Flavobacterium psychrophilum (GenBank accession number D12670; FpR: 5'-CGA TCC TAC TTG CGT AG-3'; FpF: 5' - CGG CCA GAT AAG TCA GTG GT-3'), Lactococcus garvieae (GenBank accession number FJ915634; LgF: 5'-CCA ACT TCC GTG GTG TGA CG-3'; LgR 5'-AGT GGC TCA ACC ATT GTG TGC-3'), and Pseudomonas putida (GenBank accession number GU248219; PpF: 5'-CCA AAA CTG GCA AGC TAG AGT AC-3'; PpR: 5'-CAT CTC TGG AAA GTT CTC TGC-3') were selected. Primers used in the detection of $P$. aeruginosa (PaF: 5'GGG GGA TCT TCG GAC CTC A-3'; PaSR: 5'-TCC TTA GAG TGC CCA CCC G-3') were described by Spilker et al. (2004).

Different annealing temperatures and $\mathrm{MgCl}_{2}$ concentrations were tested to obtain the optimal specificity and sensitivity of the MPCR assay. Intensity of the amplicons for each target DNA, as well as the absence of unspecific bands, was considered in selecting the optimal mPCR conditions. The best results were obtained with an annealing temperature of $60^{\circ} \mathrm{C}$ and $3 \mathrm{mM} \mathrm{MgCl}_{2}$. Each $35 \mu \mathrm{lmPCR}$ reaction mixture (prepared on ice) contained $100 \mathrm{ng}$ of the sample DNA, $17.5 \mu \mathrm{l}$ of $2 \times$ Multiplex PCR mixture containing $3 \mathrm{mM}$ $\mathrm{MgCl}_{2}$ (QIAGEN Multiplex PCR kit, Qiagen Molecular Biochemicals), $3.5 \mu$ l of $5 \times$ Q solution (QIAGEN Multiplex PCR kit), and $100 \mathrm{ng}$ of each primer (Iontek).

Thermal cycling was performed with a Thermo Hybaid thermal cycler (Thermo Electron) under the following conditions: an initial denaturation cycle at $95^{\circ} \mathrm{C}$ for $15 \mathrm{~min}$, followed by 30 cycles of amplification (denaturation at $94^{\circ} \mathrm{C}$ for $30 \mathrm{~s}$, annealing at $60^{\circ} \mathrm{C}$ for $90 \mathrm{~s}$, and extension at $72^{\circ} \mathrm{C}$ for $60 \mathrm{~s}$ ), and a final $10 \mathrm{~min}$ extension period at $72^{\circ} \mathrm{C}$. Controls consisted of the PCR mixture containing (1) no DNA template (reagent control), (2) DNA from negative control fish (negative control), or (3) DNA from Flavobacterium psychrophilum, Lactococcus garvieae, Pseudomonas aeruginosa, and P. putida cultures (positive control). After the PCR, products were transferred to a $2.0 \%$ agarose gel, electrophoresed, and DNA was visualized by ethidium bromide staining. 
Sensitivity and specificity of the MPCR assay. The sensitivity and specificity of the MPCR assay (combined primer sets) was tested with pure bacterial cultures and host tissue/DNA spiked with bacterial cells. Bacterial suspensions of each target strain were prepared from log phase cultures in TSB or MAOB (APHA et al. 1998). To test sensitivity of the mPCR assay with pure cultures of the target species, the bacterial suspensions were serially diluted, mixed in equal volumes for each dilution, i.e. $1 \mathrm{ml}$ of each bacterium dilution was mixed in $5 \mathrm{ml}$ centrifuge tubes, the cells pelleted, and then the DNA extracted from each dilution mixture as described previously, and resuspended in $100 \mu \mathrm{l}$ TE buffer. If extracted DNA concentrations were more than $100 \mathrm{ng} \mathrm{ll}^{-1}$, DNA was diluted to reach $100 \mathrm{ng} \mathrm{l}^{-1}$, and $1 \mu \mathrm{l}$ was used per reaction. If extracted DNA concentrations were less than $100 \mathrm{ng}^{-1}, 1 \mu \mathrm{l}$ of DNA extract was directly used per reaction without dilution. All mPCRs assessing limits of detection were performed in triplicate.

To test the sensitivity of the mPCR assay in the presence of fish tissue, spiked samples were used. One gram rainbow trout liver was homogenized with lysis buffer in a 1:10 ratio and seeded with serial dilutions of an equal mixture of pure cultures of the 4 bacterial species (del Cerro et al. 2002, Altinok et al. 2008). DNA was extracted as described previously for tissue samples.

To enumerate the target bacterial strains used for DNA extraction, $0.1 \mathrm{ml}$ aliquots of the serially diluted bacteria used in the DNA extractions were spread onto TSA for Lactococcus garvieae, Pseudomonas aeruginosa, and P. putida and MAO agar for Flavobacterium psychrophilum. Bacteria were incubated at $25^{\circ} \mathrm{C}$ for $2 \mathrm{~d}$, except F. psychrophilum, which was incubated at $18^{\circ} \mathrm{C}$ for $4 \mathrm{~d}$.

To test specificity of the mPCR primers, DNA from target or non-target species (Table 1), extracted as described previously and diluted to $100 \mathrm{ng} \mathrm{\mu l}^{-1}$, was tested individually in PCR reactions containing either single primer-pairs or all primer-pairs mixed together in equal concentrations (100 $\mathrm{ng}$ for each primer), i.e. in mPCR format.

To check specificity of the MPCR assay (combined primer sets) primers for target and non-target bacterial species in association with host DNA, 500 ng host DNA were spiked with approximately 105 colony-forming units (CFU) of each target species and $105 \mathrm{CFU}$ of a non-target species from Table 1. The DNA was then purified as described above for tissue samples and diluted to $100 \mathrm{ng}^{-1} \mathrm{l}^{-1}$. This was repeated with each non-target species in Table 1, and was again repeated using $100 \mathrm{mg}$ of homogenized fish liver tissue in place of $500 \mathrm{ng}$ extracted host DNA. DNA concentration was measured and diluted to $100 \mathrm{ng} \mathrm{\mu l}^{-1}$. Prior to these experiments, host tissue was checked for the presence of targeted species using PCR.

To test the effect of a high amount of 1 pathogen to low amounts of the other 3 species in the MPCR reaction, $100 \mathrm{mg}$ of rainbow trout liver were homogenized with lysis buffer in a 1:10 ratio and mixed with different amounts of Flavobacterium psychrophilum, Lactococcus garvieae, Pseudomonas aeruginosa, and P. putida (see Tables $2 \& 3$ ). DNA was extracted from the mixture as described for tissue samples above. All mPCR reactions assessing limits of detection were performed in triplicate.

Sequencing method. To verify that their respective specific primer pairs amplified Flavobacterium psychrophilum, Lactococcus garvieae, Pseudomonas aeruginosa, and P. putida DNA, the PCR products generated using the $\mathrm{MPCR}$ assay were purified with a NucleoSpin PCR purification kit (Macherey-Nagel) and directly sequenced with an ABI PRISM 310 genetic analyzer (Applied Biosystems). Both strands of the PCR templates were sequenced. The nucleotide sequences were analyzed and aligned with BioEdit Sequence Alignment Editor (North Carolina State University, Raleigh, NC). The results of the sequencing were used for homology searches following the methods of Altschul et al. (1990).

\section{RESULTS}

Each of the 4 pairs of oligonucleotide primers exclusively amplified the $16 \mathrm{~S}$ rDNA of their specific targeted microorganism. An amplification product of the expected size was observed from pure cultures of 2 strains of Flavobacterium psychrophilum (685 bp), 4 strains of Lactococcus garvieae (857 bp), 2 strains of Pseudomonas putida (380 bp), and 1 strain of $P$. aeruginosa (956 bp; Fig. 1). The specificity of the assay was further verified by performing the mPCR with DNA from cultures of taxonomically and/or ecologically related non-target bacterial species. In all cases, no PCR products were obtained, demonstrating that the mPCR assay did not cross-react with these species.

The specificity of the primers, both singly and as a multiplex, was also tested against all target and nontarget bacterial species in the presence of host DNA. No cross reactivity was observed.

The average detection limits in the MPCR for each species were $2 \mathrm{CFU}$ for Flavobacterium psychrophilum, 3 CFU for Lactococcus garvieae, 3 CFU for Pseudomonas aeruginosa, and $5 \mathrm{CFU}$ for $P$. putida when pure mixed species cultures were used. The detection limits for the spiked samples were $50 \mathrm{CFU} \mathrm{g}^{-1}$ of tissue for F. psychrophilum, $60 \mathrm{CFU}$ for L. garvieae, $30 \mathrm{CFU}$ for P. aeruginosa, and 45 CFU for P. putida (Fig. 2). 


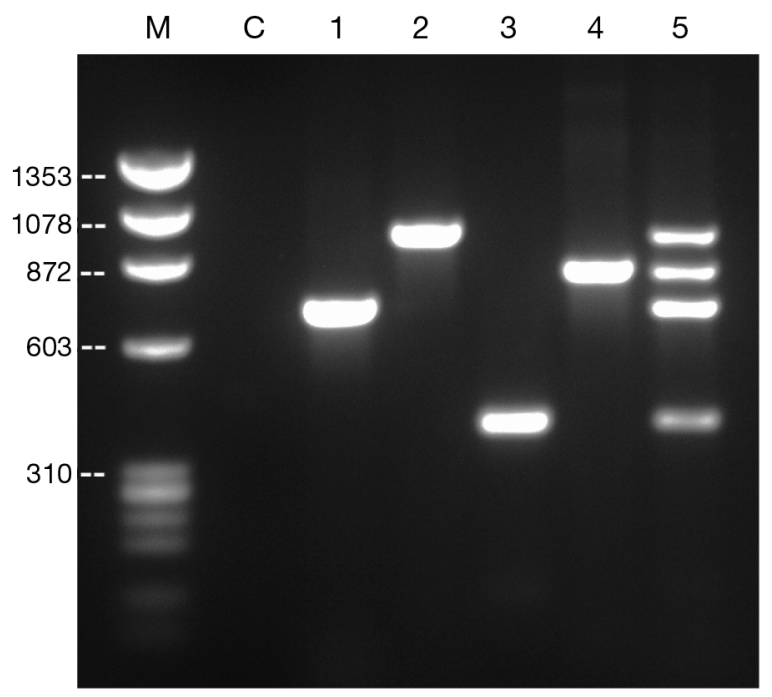

Fig. 1. Specificity of the mPCR assay developed for the detection of Flavobacterium psychrophilum, Lactococcus garvieae, Pseudomonas aeruginosa, and P. putida. Lane M: Phi X174 DNA/HaeIII molecular size marker; Lane C: negative control containing PCR reagents alone; Lane 1: F. psychrophilum (685 bp) alone; Lane 2: P. aeruginosa (956 bp) alone; Lane 3: P. putida (380 bp) alone; Lane 4: L. garvieae (857 bp) alone;

Lane 5: mPCR with the 4 pathogens together

High amounts of DNA from 1 bacterial species had a significant effect on the amplification sensitivity of the other bacterial species when these were present in lower concentrations in the multiplex reaction. The detection limits of the mPCR for Flavobacterium psychrophilum and Lactococcus garvieae were higher when high amounts of amplification of the other target bacterial

Table 2. Amplified band intensity in the multiplex PCR containing a high amount of 1 pathogen (1000 colony-forming units, CFU) and low amounts of the other 3 pathogens (6 CFU or $12 \mathrm{CFU}$ ). Band intensity was estimated by Kodak Gel logic 200 software (version 4.1). CFU of bacteria were estimated based on the McFarland standard. For band intensities, faint: intensity is $<10 \mathrm{ng}_{i}+$ : 11-99 $\mathrm{ng}_{;}+++$: 200-299 $\mathrm{ng}_{i}++++$ : $>300 \mathrm{ng}$

\begin{tabular}{|c|c|c|c|c|}
\hline \multirow[t]{2}{*}{ Primer set specificity } & \multicolumn{4}{|c|}{ - Pathogen at $1000 \mathrm{CFU}$} \\
\hline & $\begin{array}{l}\text { F. psychro- } \\
\text { philum }\end{array}$ & $\begin{array}{c}\text { L. } \\
\text { garvieae }\end{array}$ & $\begin{array}{c}P . \\
\text { aeruginosa }\end{array}$ & $\begin{array}{c}\text { P. } \\
\text { putida }\end{array}$ \\
\hline \multicolumn{5}{|l|}{ Remaining pathogens at 6 CFU } \\
\hline Flavobacterium psychrophilum & ++++ & None & None & None \\
\hline Lactococcus garvieae & None & ++++ & None & None \\
\hline Pseudomonas aeruginosa & Faint & Faint & ++++ & Faint \\
\hline P. putida & None & Faint & Faint & ++++ \\
\hline \multicolumn{5}{|l|}{ Remaining pathogens at $12 \mathrm{CFU}$} \\
\hline Flavobacterium psychrophilum & +++ & + & + & + \\
\hline Lactococcus garvieae & Faint & +++ & + & + \\
\hline Pseudomonas aeruginosa & + & + & +++ & + \\
\hline P. putida & + & + & + & ++++ \\
\hline
\end{tabular}

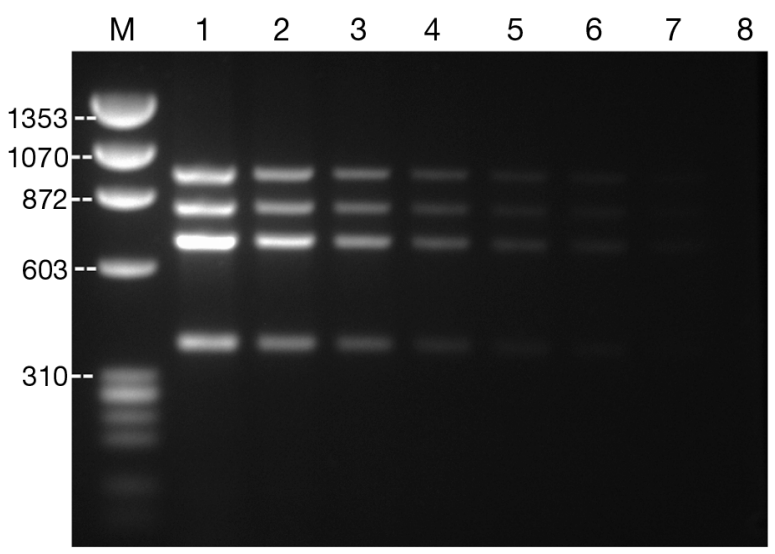

Fig. 2. Sensitivity of the detection of Flavobacterium psychrophilum, Lactococcus garvieae, Pseudomonas aeruginosa, and $P$. putida by mPCR assay. PCR product sizes obtained for $F$. psychrophilum, L. garvieae, $P$. aeruginosa, and $P$. putida were 685, 857, 956, and $380 \mathrm{bp}$, respectively. PCR amplification on tissue samples seeded with serially diluted cultures of the 4 pathogens. Lane M: Phi X174 DNA/HaeIII molecular size marker; Lanes 1 to $8: 10^{-1}$ to $10^{-8}$ dilutions, respectively. Undiluted medium contained $50 \times 10^{7}, 60 \times 10^{7}, 30 \times 10^{7}$, and $45 \times 10^{7} \mathrm{CFU} \mathrm{g}^{-1}$ tissue of F. psychrophilum, L. garvieae, $P$. aeruginosa, and $P$. putida, respectively. The $10^{-7}$ dilution was the most dilute sample that was PCR-positive for the 4 bacteria

DNA occurred (Table 2). All bacterial species could be detected at a lower concentration limit of $12 \mathrm{CFU}$ per $100 \mathrm{mg}$ of tissue irrespective of the concentration of the other target species in the mPCR reaction (1000 CFU being the highest concentration used; Table 2). Amplified band intensity of the multiplex PCR products was the same when the reaction contained the same amounts of targeted species (Table 3). When the concentration of any of the target species was $\geq 25 \mathrm{CFU}$ per $100 \mathrm{mg}$ of tissue, a higher amount of 1 pathogen DNA (1000 CFU being the highest concentration used) did not affect the observed intensity of the products on an agarose gel (Table 3).

Of 780 rainbow trout examined from 32 hatcheries, only 25 fish showed clinical disease symptoms. F. psychrophilum, L. garvieae, and $P$. putida were respectively isolated from 1,7 , and 2 fish that had clinical signs of disease (Table 4). None of the 4 targeted species were found using culture or $\mathrm{mPCR}$ in the 15 remaining fish displaying clinical signs, although Yersinia ruckeri, Aeromonas hydrophila, A. salmonicida salmonicida, and P. fluorescens were subsequently isolated in cultures. 
Table 3. Amplified band intensity of multiplex PCR containing various proportions of colony-forming units (CFU) each of Flavobacterium psychrophilum, Lactococcus garvieae, Pseudomonas aeruginosa, and $P$. putida. Band intensity was estimated by Kodak Gel logic 200 software (version 4.1). For band intensities, ++: 100-199 $\mathrm{ng}_{i}+++$ : 200-299 ng

\begin{tabular}{|lccrc|}
\hline Bacteria & CFU & $\begin{array}{c}\text { Band } \\
\text { intensity }\end{array}$ & CFU & $\begin{array}{c}\text { Band } \\
\text { intensity }\end{array}$ \\
\hline F. psychrophilum & 50 & +++ & 1000 & +++ \\
L. garvieae & 50 & +++ & 100 & ++ \\
P. aeruginosa & 50 & +++ & 50 & ++ \\
P. putida & 50 & +++ & 25 & ++ \\
\hline
\end{tabular}

Flavobacterium psychrophilum, Lactococcus garvieae, Pseudomonas aeruginosa, and $P$. putida were isolated from $2,20,3$, and 2 fish, respectively, using culture methods. Seventy-nine fish were positive for the presence of target species using the mPCR. Mixed infections of 2 and 3 bacterial species were found in 24 and 9 fish, respectively, resulting in identification of $F$. psychrophilum from 8 fish, $L$. garvieae from 45 fish, $P$. aeruginosa from 15 fish, and $P$. putida from 11 fish (Table 4). No individual fish was positive by MPCR for all 4 target bacterial species. The culture method did not pick up mixed infections for the target bacterial species. All culture-positive fish were also $\mathrm{mPCR}$-positive.

Sequences of the amplified DNA products, of different expected sizes, from 3 fish matched the sequence of the 4 target bacterial species.

Some of the bacterial infections showed seasonality. While Lactococcus garvieae and Pseudomonas aeruginosa infections were common throughout the year, $P$. putida and Flavobacterium psychrophilum infection were common in spring and in winter, respectively.

\section{DISCUSSION}

Specific primers for Flavobacterium psychrophilum, Lactococcus garvieae, and Pseudomonas putida were developed and their sensitivity and specificity, in a multiplex PCR format, were tested in the present study. The assay appeared to be very sensitive, with a detection limit of as low as $60 \mathrm{CFU} \mathrm{g}^{-1}$ of tissue for all 4 bacteria. As the data were based on colony counts, it seems reasonable to expect that the number of colonies would be an underestimation of the total number of bacterial cells present (Barbosa et al. 1995); however, the mPCR detection limits are similar to PCR detection limits previously reported in the literature for other bacterial species (Brown et al. 1994, Nielsen et al. 2001, del Cerro et al. 2002). The primers described here proved to be specific under the conditions assayed both in relation to the 4 target species and the other closely related bacterial species tested, with only the specific target species showing amplification in the multiplex reaction.

PCR assays may vary in amplification efficiency, due to primer length, nucleotide content, and secondary structure. It is therefore important to see whether 1 PCR assay within the multiplex against a target in high concentration might outcompete 1 or more of the other assays to such an extent that the detection limits for the targets at lower concentrations are affected. In the present study, higher concentrations of DNA from 1 pathogen had a noticeable effect on amplification of other bacteria in the multiplex reaction when these were present at very low levels. However, bacterial concentrations of $12 \mathrm{CFU}$ per $100 \mathrm{mg}$ of tissue allowed detection of all target species by the MPCR in the presence of the higher competing DNA concentrations tested.

Healthy-looking fish without clinical signs or lesions can carry pathogens that create serious risks for the spread of contagious diseases in fish populations. Disease becomes evident only when stressful conditions arise, as can occur under intensive aquaculture conditions, and a significant proportion of the stock may become infected and die as a result. Therefore, detection of pathogens in carrier fish is essential for effective disease control. Prevalence of disease may change depending on the time of year and water temperature (Plumb 1999), making it difficult to identify infected fish in a population at certain times. In addition, detection of bacteria using culture methods may prove difficult in asymptomatic fish due

Table 4. Comparison of culture and mPCR methods

\begin{tabular}{|lcrrr|r|}
\hline Bacterial species detected & $\begin{array}{c}\text { No. of fish with } \\
\text { clinical signs }\end{array}$ & $\begin{array}{c}\text { No. of positive fish } \\
\text { Culture }\end{array}$ & \multicolumn{2}{c|}{$\begin{array}{c}\text { No. of fish with mixed infections } \\
\text { 2 bacterial species }\end{array}$} & 3 bacterial species \\
\hline Flavobacterium psychrophilum & 1 & 2 & 8 & 2 & 2 \\
Lactococcus garvieae & 7 & 20 & 45 & 5 & 3 \\
Pseudomonas aeruginosa & 0 & 3 & 15 & 4 & 2 \\
P. putida & 2 & 2 & 11 & 4 \\
\hline
\end{tabular}


to low pathogen levels. From the data presented here, we conclude that the multiplex PCR assay is more sensitive than bacteriological culturing. Twentyseven fish were positive for the target species by culture, while 79 fish were positive by mPCR, with mPCR detecting target pathogens from higher numbers of asymptomatic fish.

In addition, compared to standard bacteriological assays, the mPCR assay is much more rapid to perform. Therefore, this assay represents an important diagnostic tool to detect fish carrying the common pathogens Flavobacterium psychrophilum, Lactococcus garvieae, Pseudomonas aeruginosa, and P. putida especially when low prevalence is expected and large numbers of fish need to be analyzed. It may be applicable for epidemiological and transmission studies and can contribute to efforts to control or eradicate bacterial infections.

The availability of rapid, sensitive, and specific diagnostic methods for the detection of bacterial pathogens causing disease is very important in aquaculture. The results indicate that the $\mathrm{MPCR}$ developed within this study is a highly sensitive and specific method for detecting Flavobacterium psychrophilum, Lactococcus garvieae, Pseudomonas aeruginosa, and P. putida in fish farm outbreaks. The mPCR assay allows a rapid and reliable diagnosis of disease to be carried out in a single PCR assay.

Acknowledgements. This project was funded by Karadeniz Technical University, Research Project fund (project no: 2008.117.01.2). I thank E. Capkin, S. Kayis, and H. Boran for assistance during the preparation of this manuscript.

\section{LITERATURE CITED}

Altinok I, Grizzle JM, Liu Z (2001) Detection of Yersinia ruckeri in rainbow trout blood by use of the polymerase chain reaction. Dis Aquat Org 44:29-34

Altinok I, Kayis S, Capkin E (2006) Pseudomonas putida infection in rainbow trout. Aquaculture 261:850-855

Altinok I, Capkin E, Kayis S (2008) Development of multiplex PCR assay for simultaneous detection of five bacterial fish pathogens. Vet Microbiol 131:332-338

Altschul SF, Gish W, Miller W, Myers EW, Lipman DJ (1990) Basic local alignment search tool. J Mol Biol 215:403-410

APHA (American Public Health Association), American Water Works Association, Water Environment Federation (1998) Standard methods for the examination of water and wastewater, 20th edn. APHA, Washington, DC

Austin B, Austin DA (2007) Bacterial fish pathogens: diseases of farmed and wild fish, 4th edn. Praxis Publishing, Chichester

Barbosa HR, Rodrigues MFA, Campos CC, Chaves ME, Nunes I, Juliano Y, Novo NF (1995) Counting of viable cluster-forming and non cluster-forming bacteria: a comparison between the drop and the spread methods. J Microbiol Methods 22:39-50
Bernardet JF, Campbell AC, Buswell JA (1990) Flexibacter maritimus is the agent of 'black patch necrosis' in Dover sole in Scotland. Dis Aquat Org 8:233-237

Bertolini JM, Rohovec JS (1992) Electrophoretic detection of proteases from different Flavobacterium columnare strains and assessment of their variability. Dis Aquat Org 12:121-128

Bouallegue O, Mzoughi R, Weill FX, Mahdhaoui N and others (2004) Outbreak of Pseudomonas putida bacteraemia in a neonatal intensive care unit. J Hosp Infect 57:88-91

Brasher CW, DePaola A, Jones DD, Bej AK (1998) Detection of microbial pathogens in shellfish with multiplex PCR. Curr Microbiol 37:101-107

> Brown LL, Iwama GK, Evelyn TPT, Nelson WS, Levine RP (1994) Use of the polymerase chain reaction (PCR) to detect DNA from Renibacterium salmoninarum within individual salmonid eggs. Dis Aquat Org 18:165-171

Chen MF, Henry-Ford D, Groff JM (1995) Isolation and characterization of Flexibacter maritimus from marine fishes of California. J Aquat Anim Health 7:318-326

Cowan ST (1974) Manual for the identification of medical bacteria. Cambridge University Press, Cambridge

> Dalsgaard I, Madsen L (2000) Bacterial pathogens in rainbow trout, Oncorhynchus mykiss (Walbaum), reared at Danish freshwater farms. J Fish Dis 23:199-209

del Cerro A, Marquez I, Guijarro JA (2002) Simultaneous detection of Aeromonas salmonicida, Flavobacterium psychrophilum, and Yersinia ruckeri, three major fish pathogens, by multiplex PCR. Appl Environ Microbiol 68: $5177-5180$

Elliott JA, Collins MD, Pigott E, Facklam RR (1991) Differentiation of Lactococcus lactis and Lactococcus garvieae from humans by comparison of whole-cell protein patterns. J Clin Microbiol 29:2731-2734

Evans JJ, Pasnik DJ, Klesius PH, Al-Ablani S (2006) First report of Streptococcus agalactiae and Lactococcus garvieae from a wild bottlenose dolphin (Tursiops truncatus). J Wildl Dis 42:561-569

Frerichs GN (1984) Isolation and identification of fish bacterial pathogens. Institute of Aquaculture, University of Stirling

Holt JG, Krieg NR, Sneath PHA, Staley JT, Williams ST (1994) Bergey's manual of determinative bacteriology. Lippincott Williams and Wilkins, Baltimore, MD

Hossain MI, Neela FA, Hussain MA, Rahman MH, Suzuki S (2006) Distribution of Pseudomonas aeruginosa in swamps and its infection to Oreochromis niloticus. J Biosci 14: $77-81$

Hudson VL, Wielinski CL, Regelmann WE (1993) Prognostic implications of initial oropharyngeal bacterial flora in patients with cystic fibrosis diagnosed before the age of two years. J Pediatr 122:854-860

Krieg NR, Holt JG (1984) Bergey's manual of systematic bacteriology, Vol 1. Williams and Wilkins, Baltimore, MD

Lennette EIL, Balows A, Mausler WJ, Shadomy HJ (1985) Manual of clinical microbiology, 4th edn. American Society for Microbiology, Washington, DC

Mata AI, Gibello A, Casamayor A, Blanco MM, Domínguez L, Fernandez-Garayzabal JF (2004) Multiplex PCR assay for detection of bacterial pathogens associated with warmwater streptococcosis in fish. Appl Environ Microbiol 70: 3183-3187

Nielsen ME, Høi L, Schmidt AS, Qian D, Shimada T, Shen JY, Larsen JL (2001) Is Aeromonas hydrophila the dominant motile Aeromonas species that causes disease outbreaks in aquaculture production in the Zhejiang Province of China? Dis Aquat Org 46:23-29 
Osorio CR, Toranzo AE, Romalde JL, Barja JL (2000) Multiplex PCR assay for ureC and 16S rRNA genes clearly discriminates between both subspecies of Photobacterium damselae. Dis Aquat Org 40:177-183

Pazos F, Santos Y, Macias AR, Nuñez S, Toranzo AE (1996) Evaluation of media for the successful culture of Flexibacter maritimus. J Fish Dis 19:193-197

Plumb JA (1999) Health maintenance and principal microbial diseases of cultured fishes. Iowa State University Press, Ames, IA

Pyle SW, Shotts EB (1980) A new approach for differentiating Flexibacteria isolated from cold-water and warmwater fish. Can J Fish Aquat Sci 37:1040-1042

Editorial responsibility: Catherine Collins, Aberdeen, UK
Spanoghe L (1984) The significance of Pseudomonas aeruginosa infections in animals. Ant Leeuwenhoek 50:290

Spilker T, Coenye T, Vandamme P, LiPuma JJ (2004) PCR-based assay for differentiation of Pseudomonas aeruginosa from other Pseudomonas species recovered from cystic fibrosis patients. J Clin Microbiol 42: 2074-2079

Toranzo AE, Barja JL (1993) Fry mortality syndrome (FMS) in Spain. Isolation of the causative bacterium Flexibacter psychrophilus. Bull Eur Assoc Fish Pathol 13:30-32

Woo PTK, Bruno DW (1999) Fish diseases and disorders, Vol 3. CABI Publishing, Wallingford

Submitted: March 23, 2010; Accepted: October 11, 2010 Proofs received from author(s): February 5, 2011 